Scientiæ studia, São Paulo, v. 6, n. 1, p. 117-37, 2008

\title{
ist \\ Formas do vivo e no vivo: imitar e/ou reproduzir a vida'
}

Anne Marcovich

\begin{abstract}
is
RESUMO

As questões relativas às formas e à morfologia adquiriram depois do século xvııI uma posição central nas ciências e, particularmente, na biologia. Desde 1890, as formas surgiram na bioquímica a partir da noção de especificidade (fala-se da adequação entre moléculas como daquela entre uma chave e uma fechadura). As diferentes orientações na biologia (particularmente depois da revolução da biologia molecular, do desenvolvimento da biologia sistêmica, da biologia sintética e dos trabalhos claramente orientados para as escalas nanométricas) produziram significações diferenciadas das noções de forma e de especificidade. As diferentes perspectivas, nas quais elas são utilizadas, principalmente, na questão das fronteiras entre vivo e não vivo, entre natureza e artifício, ou, ao contrário, nas quais elas são eliminadas, substituídas, por exemplo, pelas noções de informação e de código, poderiam fornecer a chave para compreender a epistemologia profunda da pesquisa nesses domínios e os "paradigmas" que congregam pesquisadores que trabalham originalmente em comunidades científicas distintas. As análises aqui propostas apóiam-se principalmente na idéia de invariabilidade dos conceitos e das idéias que, mais ou menos explicitamente, possam assemelhar-se a princípios organizadores das atividades científicas.
\end{abstract}

Palavras-chave: Biologia molecular. Biologia sistêmica. Biologia sintética. Comunidade científica. (Des)-contextualização. Epistemologia. Forma. Fronteira. Invariabilidade. Modelo. Especificidade.

As questões de forma e de morfologia são centrais, sobretudo a partir do século xviıI, para classificar os seres em espécies, famílias, genêros: Emil Fischer, ${ }^{2}$ especialista em proteínas, emprega esse termo pela primeira vez a propósito das propriedades de enzimas capazes de reconhecer a estrutura química das moléculas sobre as quais elas agem, seus substratos. Para ilustrar essa notável adequação, Fischer utiliza a imagem da chave e da fechadura. $\mathrm{O}$ substrato reage com a enzima como uma chave com sua

1 Este artigo apresenta alguns elementos de uma reflexão em curso e não tem, portanto, outra pretensão que indicar algumas pistas. Ele se apóia em parte em uma comunicação feita no workshop "Para uma avaliação crítica das bionanotecnologias. Perspectivas éticas e filosóficas”, ocorrido em 25 e 26 de janeiro de 2008, na École Normale Supérieure - Rue d'Ulm, Paris, França.

2 Hermann Emil Fischer, químico alemão, recebeu o Prêmio Nobel de química em 1902 por seus trabalhos sobre a síntese dos hidratos de carbono e das purinas. 
fechadura. Essa noção de especificidade de reconhecimento torna-se uma propriedade intrínseca da vida (cf. Morange, 2003, p. 20). Ela implica que a forma contribui para definir as propriedades do organismo vivo, ou de uma de suas componentes, e determina, ao mesmo tempo, o tipo de relação que ele pode ter com seu ambiente.

As diferentes orientações que se desenvolveram na biologia, principalmente depois da revolução da biologia molecular (interessam aqui a biologia sistêmica, a biologia sintética e os trabalhos nitidamente orientados para as escalas nanométricas), dão um lugar essencial a essas noções de forma e especificidade. Mas elas adquirem um peso e são contidas por perspectivas diferentes, que poderiam fornecer a chave para compreender a epistemologia, que está na base das pesquisas nesses domínios, e os "paradigmas" que congregam pesquisadores, que trabalham originalmente em comunidades distintas e que os remetem freqüentemente aos problemas fundamentais. Em primeiro lugar, a questão da fronteira entre vivo e não vivo, com sua variante da origem da vida; em segundo lugar, e relacionada com a primeira questão, aquela de todas as hubris que desfazem as fronteiras entre a natureza e o artifício e, finalmente, aquela dos agregados ou entidades que são considerados: a molécula, a célula, ... o organismo inteiro, e as relações entre eles, sem as quais a "vida" não existiria. Este último ponto atravessa toda a história das ciências biológicas. Ele permite esclarecer, para além da diversidade de abordagens, os métodos e as técnicas empregados no decorrer do tempo, o modo pelo qual se compreendem as relações entre os mecanismos do que é vivo, os quais se consegue desnudar em um momento dado, e o organismo inteiro, no qual eles se inserem.

Para melhor apreender certas injunções e as significações profundas que podem camuflar essa questão da forma nas ciências da vida, debruçar-nos-emos inicialmente sobre os trabalhos de um autor, Stephane Leduc $\left(185^{3-1939)},{ }^{3}\right.$ médico francês do início do século xx, que tinha feito a aposta de mostrar que as formas de vida dependiam essencialmente de leis químicas e mecânicas. Consideraremos a seguir, sempre a propósito dessa questão da forma, como se fundou a biologia molecular, verdadeira matriz de desenvolvimento das ciências da vida no final do século xx e início do século xxI, antes de examinar a biologia sistêmica e a biologia sintética.

3 Há duas versões de sua principal obra: uma versão inglesa, intitulada The mechanism of life (1911), e uma versão francesa, com o título Le mouvement crée les formes. La biologie sinthétique (1912). Utilizaremos nesta discussão a versão que se encontra na internet. 


\section{UMA ABORDAGEM DAS FORMAS QUE IMITAM A VIDA: QUAIS PARADIGMAS?}

Para Leduc, assim como, em parte, para D’Arcy Wentworth Thomson (1860-1948), "a forma mais harmoniosa e mais realizada de seres vivos não testemunha um plano sobrenatural, mas resulta do jogo das leis naturais [...]. O objetivo é compreender os princípios básicos de sua formação e de suas estruturas sutis e enigmáticas" (Bensaude, no prelo). Estamos aqui na concepção formada por Condillac, desenvolvida por Lavoisier e depois por Berthelot, que parte do mais elementar para chegar ao mais complexo. As propriedades físico-químicas dos materiais utilizados são suficientes para o desenvolvimento das formas que imitam a vida. $\mathrm{O}$ que as engendra são o movimento e as resistências que a ele se opõem. Leduc o exprime assim:

o fato de que as formas e as estruturas sejam a expressão de movimentos e de forças que os realizam e que os engendram e, de outro lado, a uniformidade da estrutura dinâmica de muitos fenômenos do universo dão a explicação física das admiráveis e surpreendentes analogias das formas observadas nas produções da natureza, que parecem estar mais afastadas e serem estranhas entre si (Leduc, 2008).

As formas que assim se constroem receptam uma harmonia que parece provir diretamente do trabalho de forças no seio da matéria. Elas parecem, de certo modo, obras de arte, e pode-se contemplá-las enquanto tal. Nessa perspectiva, elas poderiam ser analisadas, como faz Petitot a propósito do estudo de Goethe sobre o Laoconte. "A 'formação' (Bildung), para Goethe, é o 'desdobramento-redesdobramento espaçotemporal de uma força organizadora interna que passa à existência manifestando-se espaço-temporalmente" (Petitot, 2004, p. 16). Nessa semiótica da forma desenvolvida por Petitot, põe-se nitidamente a questão de uma relação dialética entre a estrutura interna e a forma externa.

As formas minerais de Leduc, que imitam a vida, são o resultado de processos puramente mecânicos e químicos, e não se deve certamente ver nelas tentativas demiúrgicas de criação da vida. Mas elas interpelam sobre os sentidos e sobre a relação entre a forma de um ser particular, a qual se deixa ver, e a sua estrutura interna. Estamos aqui na perspectiva de alguém que, tal como Buffon, fala de "molde interior" e para quem as propriedades particulares de uma parte dada do organismo seriam uma espécie de matriz, que determina a morfologia e a necessidade de todas as outras partes. ${ }^{4}$

4. “...] esse desenvolvimento [do animal], como se pode fazer, a não ser em consideração do corpo animal, e mesmo de cada uma de suas partes, como tantos moldes internos que não recebem a matéria acessória senão na ordem que resulta da posição de todas as partes" (Buffon apud Flourens, 1844, p. 69). 
Nesse caso, a questão, à qual retornaremos, será claramente enunciada por Schrödinger: as relações entre a estrutura interna e a forma externa podem ser enunciadas em termos da dinâmica de um programa ou de um código que organizaria do interior o desenvolvimento de um organismo e, por conseqüência, sua forma (cf. Ibrahim, 1987)? Ou no encontramos antes na lógica de Cuvier (1812), com sua lei da correlação das formas: seria possível reconstituir o agregado do corpo de um animal a partir de um só de seus órgãos? Nesse caso, a forma esclarece sobre as "necessidades" a que um organismo vivo está submetido para assegurar sua existência e sobre o encaixe recíproco das diferentes partes que o compõem.

Não se trata aqui de "descobrir" as linhagens de pensamento mais ou menos artificiais entre trabalhos distantes por mais de um século, mas de marcar, se elas existem, as constantes nas questões e os embasamentos intelectuais dos quais elas procedem.

\section{A Biologia MOLEGULAR}

\subsection{A PASSAGEM PELA FÍSica}

Apesar do movimento já ter sido tratado por físicos como Max Delbrük ou Linus Pauling, ninguém se dispõe a considerar ${ }^{5}$ que a revolução da biologia molecular foi fortemente impulsionada por Erwin Schröedinger e seu livro $O$ que é a vida?, publicado pela primeira vez em 1944.

O ponto de partida da reflexão de Schrödinger é o seguinte: "como se pode explicar com a ajuda da física e da química os acontecimentos que se produzem no espaço e no tempo nos limites espaciais de um organismo vivo?" (Schrödinger, 1992 [1944], p. 40). Esta questão programática está organizada em vários planos:

(1) aquele da ligação entre as leis da física quântica no nível do átomo, por um lado, e a célula e o órgão do organismo vivo inteiro, por outro lado;

(2) aquele da permanência, da durabilidade dos organismos vivos, dadas as possibilidades estatísticas (na escala atômica, fala-se necessariamente em termos estatísticos) de mudança na dinâmica da vida no interior de suas estruturas mais íntimas. 
Em seu prefácio ao livro de Schrödinger, Danchin resume: "toda a questão é de dar uma forma, uma estrutura a essa abundância: somente as reuniões de átomos poderão fazê-lo, sob a condição de que o agregado seja bastante estável, tenha uma duração de vida suficiente para a temperatura na qual se desenvolve a vida"; e ele acrescenta: "o modelo quântico, tão poderoso quando demonstrava que o suporte hereditário tinha necessariamente uma natureza molecular poli-atômica, não podia servir também, pelo viés da mecânica estatística, para considerar o papel da 'forma' na vida?" (Danchin, 1992, p. 9). Ora, como explica Schrödinger, "são os cromossomas [...] que contêm, sob a forma de código, o modelo integral do desenvolvimento futuro do indivíduo e de seu funcionamento no estado adulto" (Schrödinger, 1992[1944], p. 72). Schrödinger é o primeiro a servir-se do termo "código" para designar o patrimônio genético; e acrescenta:

mas o termo código é, evidentemente, muito estreito. As estruturas cromossômicas servem, ao mesmo tempo, para realizar o desenvolvimento que elas simbolizam. Elas são o código da lei e o poder executivo ou, para empregar outra analogia, elas são, ao mesmo tempo, o plano do arquiteto e a obra de arte do construtor (Schrödinger, 1992[1944], p. 72).

Essa noção de código constitui a armação do projeto da biologia molecular, pelo menos durante seus primeiros quinze anos. Ele orientará as questões sobre a organização da vida em direções que dão à noção de informação uma prevalência sobre a noção de especificidade, imprimindo assim, de uma certa maneira, um jogo de equilíbrio entre elas.

\subsection{Alguns DEgRaus DA HistóRIA DA BIOLOgia MOLEGULAR}

O lugar central das noções de forma, de configuração e de especificidade de moléculas é uma constante da história da biologia (cf. Morange, 2003). Desde 1936, utilizando os conceitos da química inorgânica, Linus Pauling, Prêmio Nobel de química em 1954 e da paz em 1962, mostrou em seus trabalhos de imunoquímica sobre as proteínas, que 0 antígeno e o anticorpo tinham estruturas complementares que se encaixavam uma na outra. Ele confirmava, assim, o modelo proposto cinqüenta anos antes por Fischer. Com Pauling, o conceito de especificidade torna-se "estéreo-especificidade, complementaridade de estrutura, conjunto de ligações fracas [...]”, noções estas que são fundamentais para compreender as interações entre as macromoléculas do que é vivo. 
Contudo, essas noções de forma, de configuração e de especificidade revelaramse um obstáculo em certos momentos cruciais do desenvolvimento da biologia molecular. A descoberta do código genético implicou, com efeito, que se dissociasse o problema da natureza do gene daquele de seu mecanismo de ação, produzindo, assim, um afastamento com relação à complexidade dos conceitos bioquímicos de especificidade.

Mais que os geneticistas, foram os físicos, em razão de sua ignorância e da repulsa que lhes inspirava a complexidade inacreditável e um tanto irracional da bioquímica, que colocaram os problemas da genética em termos de transferência de informação e aquele da natureza do gene em termos de suporte de informação. Eles deslocaram, desse modo, o problema e permitiram abstrair a noção de especificidade das conotações bioquímicas e protéicas paralisantes (Morange, 2003, p. 52).

O modelo da dupla-hélice do DNA, cuja beleza e simplicidade da estrutura revelada por Watson e Crick em 1953, tinha o grande mérito de explicar por si mesmo a propriedade auto-replicativa dos genes (cf. Morange, 2003, p. 151), difundir-se-á rapidamente. Ao mesmo tempo, impôs-se o dogma segundo o qual a informação era transferida a partir do gene para os componentes da célula que deviam exprimir os caracteres, ou seja, as proteínas, e jamais das proteínas para os genes. ${ }^{6}$ Como se fazia essa transferência de informação? Mais precisamente, como se davam as relações entre DNA, RNA e proteínas? A resposta foi a descoberta do RNA-mensageiro em 1960, por Jacob e Monod, que receberam o Prêmio Nobel em 1965 por ela. Eles descobriram que, ao emparelhar as hastes do DNA com uma cópia conforme, o RNA trazia a informação contida no DNA, para ser transcrita, por meio dos ribossomos, em proteínas. Eles estabeleceram ainda que os genes intervêm de maneira permanente na síntese das proteínas e mostraram "como um processo adaptativo, portanto, condicionado pelo meio, está, não obstante, submetido a um controle genético estrito" (Morange, 2003, p. 212).

O estudo da vida inscreveu-se com a biologia molecular em um projeto que reduziu a vida aos princípios fundamentais de transferência de informação e de ligação moleculares. Entre 1965 e 1972, o código genético foi inteiramente decifrado, os mecanismos reguladores foram caracterizados juntamente com os micro-organismos.

6 O dogma que foi abalado nos anos 1970 com a descoberta dos genes reguladores e a atualização das redes bastante complexas de organização do que é vivo, nas quais as proteínas podiam intervir nos mecanismo de transcrição do DNA. 
Não obstante, a biologia molecular foi desenvolvida com os trabalhos sobre os organismos unicelulares como as bactérias, das quais a Echeria coli é o protótipo, ou de vírus como o $\mathrm{SV}_{4} \mathrm{O}$, ou ainda, de bacteriófagos. Muitos biólogos moleculares estavam convencidos de que os conhecimentos que eles possuíam sobre os mecanismos moleculares fundamentais seriam suficientes para abordar os problemas em suspenso, tais como a morfogênese e a origem da vida (cf. Morange, 2003, p. 215). Pouco ou mal formados nas disciplinas biológicas tradicionais, muitos biólogos moleculares voltaramse, com certa ingenuidade e ignorância, para os fenômenos biológicos complexos que o reducionismo da biologia molecular não permitia alcançar. Colocava-se, talvez em parte, esse paradoxo denunciado por Bohr na sua conferência de 1932, Light and life, de que o estudo das moléculas do que é vivo implicava que se matasse o organismo: a vida era irredutível, inacessível à explicação científica.

Entretanto, desde o início dos anos 1970, a biologia molecular sofre uma metamorfose: de ciência de observação ela se transforma em ciência de intervenção, de ação. Um novo ramo da biologia molecular se desenvolve: o gênio genético, que a partir do conhecimento da seqüência dos genes pode modificá-la, ${ }^{7}$ constitui um dos pilares da biologia sintética que se desenvolverá mais tarde. O gênio genético retira a dificuldade levantada por Bohr de que o estudo das moléculas do vivente implicava que se matasse o organismo. Pode-se agora estudar o papel das moléculas do vivente sem suprimir a vida, decifrando a linguagem, do mesmo modo que a criança faz para dominar a linguagem materna, imitando as frases do vivente. "O seqüenciamento do genoma humano e dos genomas de outros organismos lhes fornece o 'grande livro' da vida. Conhecerão, por isso, a linguagem do vivente? Mas conhecemos a linguagem que falamos? O que quer dizer conhecer? Será controlar cada vez melhor os usos? Ou compreender-lhes melhor a origem?" (Morange, 2003, p. 286). Questões profundas que restituem o debate naquela questão fundamental de saber o que é a vida.

Veremos que entre a biologia sistêmica e a biologia sintética traça-se uma linha de divisão que diferencia nitidamente aqueles que identificam o conhecimento da vida à capacidade de controlar e reproduzir seus mecanismos mais íntimos daqueles que vêem, em sua origem e suas evoluções, um mistério, ao mesmo tempo, necessário e

${ }_{7}$ Em 1972, David Jackson, Robert Symons e Paul Berg, da Universidade de Stanford, Califórnia, descreveram a primeira recombinação genética obtida in vitro entre as moléculas de DNA de origens específicas diferentes, a de um vírus de macaco e a de uma bactéria. A molécula que eles obtêm pode se integrar nos cromossomos de uma célula de mamífero. Como ela provém em parte de um fago, ela poderá replicar-se de maneira autônoma nas bactérias. A molécula híbrida poderá, portanto, ser aí amplificada, multiplicada. Paul Berg e seus colaboradores já visavam, portanto, "a utilização dupla e complementar da manipulação de genes: a possibilidade de introduzir os genes no organismo escolhido, mas também a utilização de bactérias para amplificar as moléculas híbridas obtidas in vitro" (Morange, 2003, p. 244). 
irredutível. Entretanto, os dados moleculares permitiram abordar a questão da evolução e da origem da vida. Foi possível obter dados quantitativos, que permitiram determinar a "distância genética" entre espécies diferentes, e deduzir, da distância genética, um tempo de "divergência" das espécies consideradas (cf. Morange, 2003, p. 327).

Se as noções de formas e especificidade tinham sido paralisantes nos trabalhos pioneiros da biologia molecular, elas retomam seu lugar depois dos anos $1965 \mathrm{com}$ as pesquisas sobre os genes reguladores. Ademais, elas retiveram toda sua pertinência nos trabalhos sobre as proteínas. Conhecia-se sua estrutura, sua função e sua especificidade bem antes, freqüentemente, de conhecer o encadeamento dos nucleotídeos nos genes, que codificavam essas proteínas. Ao mesmo tempo, conhecia-se cada vez mais seqüências de genes, e sabia-se deduzir delas as seqüências de proteínas que esses genes codificavam. Faltava a determinação das estruturas tridimensionais das proteínas que permitiam aproximar-se de sua especificidade. As famílias de proteínas que apresentavam estruturas próximas são, então, elaboradas. Interrogar-se acerca das "relações de parentesco" entre essas diferentes proteínas, do ponto de vista de suas especificidades morfológicas e químicas, tornou-se muito naturalmente um dos ângulos de ataque para abordar o estudo da origem e da evolução dos seres vivos.

A noção de especificidade, tão importante na biologia e na bioquímica, retomava seus títulos de nobreza. Ela assumiu todo seu lugar no desenvolvimento da biologia celular dos anos 1980, cujo revigoramento está ligado ao desenvolvimento de instrumentos performáticos e simples, mas também "à riqueza insuspeita do 'tráfico' intracelular" (Morange, 2003, p. 322). Ela se torna essencial nos trabalhos de biologia sistêmica nos anos 1990, depois na biologia sintética dos anos 2000 e, a partir daí, com o desenvolvimento das pesquisas do que é vivo em escalas nanométricas.

\section{DA BIOLOGIA SISTÊMiGA À BIOLOGIA SINTÉTICA}

A biologia sistêmica é uma tentativa de descrever os processos vitais em sua globalidade. Durante aproximadamente meio século, os bioquímicos e os biólogos moleculares tinham procurado compreender a "vida" decompondo a célula. Joël de Rosnay explica: "mas que coisa estranha, a cada etapa desses cortes da célula em proteínas, ácidos nucléicos e aminoácidos, a vida escapa do sistema e tudo o que resta são os progressos registrados na compreensão molecular da biologia" (Rosnay, 2008). A biologia sistêmica esforça-se para chegar a uma compreensão teórica da complexidade do vivente, unindo as competências da biologia, da física, da química, da matemática e das ciências da informação. Espera-se chegar o mais perto da verdade dos processos da vida que se desenrolam na matéria, integrando o máximo de elementos e restituindo-os 
em toda sua complexidade sob a forma de modelos. A etapa seguinte é a de construir experiências para validar ou invalidar esses modelos, graças aos quais se pretende explicar não somente os mecanismos de funcionamento dos sistemas estudados, mas igualmente predizer seu comportamento e sua evolução. A modelagem matemática tem nessas pesquisas um papel essencial.

A biologia sintética constitui, de início, um dos ramos da biologia de sistemas, mas ela se opõe a esta última em numerosos planos. Ela segue os mesmos passos, mas seu objetivo é o de fabricar os elementos do vivo com o objetivo de aplicações precisas. Ela se coloca deliberadamente em uma lógica de engenharia do vivente: ela conhece as microestruturas orgânicas artificiais, sintetiza e implanta essas microestruturas no vivente. Voltaremos a isso. O que importa sublinhar de início aqui é que os biólogos sistêmicos e os biólogos sintéticos partilham a idéia de que o vivente está ao menos parcialmente organizado em módulos. A descoberta de máquinas moleculares naturais nos organismos vivos participa dessa visão. A nanomáquina natural de ATP-sintase é um exemplo admirável. ${ }^{\mathbf{8}}$

A ATP-sintase é uma proteína membranosa (ou seja, ela se insere, graças à sua forma particular, na membrana das mitocôndrias);9 seu papel é de sintetizar a ATP (Adenosina tri-fosfato), a enzima-"recipiente" das células. Ela pode ser considerada como uma verdadeira turbina molecular. Ela é composta de duas partes, uma móvel (rotor) gira em torno de uma outra fixa (stator), ambas incluídas na membrana.

Como observa Sauvage, químico diretor do Laboratório de Química OrganoMineral (LCOM) de Strasbourg, na biologia, numerosos motores moleculares, lineares ou rotativos desempenham um papel em múltiplos processos: a síntese e a hidrólise da ATP, o transporte de moléculas, o funcionamento dos músculos estriados etc. No curso dos decênios precedentes, certos laboratórios ${ }^{10}$ propuseram sistemas moleculares complexos, totalmente artificiais, cujos comportamentos lembram máquinas ou motores primitivos. Um exemplo recente é o da molécula "músculo". Sob a ação de um sinal externo, a molécula contrai-se ou distende-se, de modo reversível. O comprimento total desse "músculo" passa de 8,5 nanômetros (na situação de distensão) a 6,5 nanômetros, quando ele se contrai (cf. Sauvage, 2008). ${ }^{11}$

8 Essa descoberta valeu o Prêmio Nobel de química de 1977 a Paul D. Boyer da Universidade da Califórnia, Los Angeles, USA, e a John E. Walker do Medical Research Council Laboratory of Molecular Biology, Cambridge, Reino Unido, que elucidaram os mecanismos enzimáticos responsáveis pela síntese da ATP, e a Jens C. Skou, da Universidade Aarhus, Dinamarca, por sua descoberta de uma enzima responsável pelo transporte de íons de sódio. Os três laureados realizaram estudos pioneiros sobre as enzimas que participam da conversão de energia na produção da ATP.

9 Organela que assegura a respiração da célula.

10 Pode-se citar a equipe de Sauvage em Strasbourg, a de Stoddart na UCLA-USA.

11 Trata-se de um sistema multicelular sintético para a formação de padrões programados. O padrão de formação é uma marca característica do comportamento celular coordenado tanto nos organismos unicelulares como nos 
Na escala nanométrica, na qual nos colocamos aqui, e que permite conceber e controlar os mecanismos físico-químicos, a saber, biológicos, em suas reduções mais íntimas, não nos interessamos somente pela forma de um objeto tal qual ela se revela em suas interações moleculares. Nós isolamos, construímos e manipulamos a forma, procurando fazer com que ela adote configurações definidas. A arquitetura molecular não é mais declinada somente em termos das ligações químicas com as restrições que elas impõem, com os ângulos que elas determinam entre suas diferentes componentes, mas enquanto ela é a conseqüência de intrinques e ajustes topológicos. ${ }^{\mathbf{1 2}}$ A equipe de Basu e colaboradores em Princeton, por exemplo, desenvolveu um sistema multicelular no qual as células geneticamente modificadas são programadas para formar sistemas moleculares na forma de anéis capazes de selecionar as moléculas emitidas pelas células "emissoras" (cf. Basu et al., 2005). O estudo cinético das transferências de moléculas entre células emissoras e receptoras mostra a prevalência das formas em anel (outras configurações tais como a elipse ou o trevo revelaram-se menos eficazes). Essa pesquisa, que uniu geneticistas, matemáticos capazes de modelar as diferentes formas de moléculas, físicos e químicos para sintetizá-las e estudá-las, biólogos para conceber e analisar o sistema celular no qual elas eram colocadas, tinha, como se pode ver, objetivos diversificados, dentre os quais aquele de compreender os processos naturais e a fabricação de materiais biológicos capazes de reparar e nutrir os tecidos de organismos vivos.

Nessa perspectiva, a noção de especificidade constituiu-se em um conjunto de relações dinâmicas entre uma molécula, da qual se conhece a estrutura, seus compor-

multicelulares. Ela envolve tipicamente a comunicação célula-célula e o processamento de sinais intracelulares. Aqui mostramos um sistema multicelular sintético, no qual células 'receptoras' geneticamente engenheiradas são programadas para formar padrões anulares de diferenciação, baseados em gradientes químicos de um sinal Acylhomoserina lactone (AHL), que é sintetizado por células 'emissoras'. Nas células receptoras, redes de genes 'detectores de bandas' respondem aos padrões de concentração de AHL definidos pelo usuário. Pela fusão de diferentes proteínas fluorescentes como resultado das variantes da rede, uma 'fina camada' inicialmente indiferenciada de receptores é engenheirada para formar um padrão olho-de-boi ao redor de uma colônia de emissores. Outros padrões, tais como elipses e trevos, são obtidos dispondo emissores em diferentes configurações. Análises experimentais e teóricas revelam quais parâmetros cinéticos afetam mais significativamente o desenvolvimento dos anéis no decorrer do tempo. A construção e o estudo de tais sistemas multicelulares sintéticos podem melhorar nosso entendimento quantitativo dos processos de desenvolvimento que ocorrem naturalmente e podem promover aplicações na engenharia de tecidos, na fabricação de biomateriais e na de biosensores.

12 Arquiteturas moleculares mecanicamente encaixadas são conexões de moléculas não por meio das ligações tradicionais, mas antes como uma conseqüência de sua topologia. Esta conexão de moléculas é análoga às teclas de um circuito de teclas em cadeia. As chaves não estão diretamente conectadas ao circuito de teclas em cadeia, mas elas não podem ser separadas sem romper o circuito. No nível molecular, as moléculas interconectadas não podem ser separadas sem distorção significativa das ligações covalentes que produzem as moléculas conectadas. Exemplos de arquiteturas moleculares mecanicamente interconectadas incluem catenanos, rotaxanos, nós moleculares e anéis moleculares borromeanos. 
tamentos íntimos e o ambiente no qual ela se localiza (uma superfície de polímero, por exemplo, enquanto ela permanece nas mãos dos químicos e físicos; uma célula, quando ela é reintroduzida no vivo). Como havíamos sublinhado anteriormente, as competências de disciplinas diferentes estão associadas nesses trabalhos. ${ }^{\mathbf{3}}$ É, em geral, uma questão diretamente ligada a um domínio da biologia, se, além disso, cada uma dessas disciplinas assim engajada pode ter objetivos apropriados de pesquisa, que as integrem. A análise cientométrica efetuada no SCI, empregando como palavras-chave "nano e especificidade" (120 itens), torna explícita a forte imbricação entre a noção de especificidade e os domínios da biologia, mesmo depois que a escala nanométrica ganhou importância. Com efeito, o estudo dos resumos dos artigos citados mostra que se trata, na sua maioria, de artigos de biologia ou de bioquímica. Além disso, a análise cientométrica com as palavras-chave "nano e bio" (4.08 itens) reforça esse ponto, na medida em que as duas curvas seguem a mesma tendência, que ficava próximo de zero em 2000, depois experimentou uma brusca ascensão que não se altera, por assim dizer, até 2008 (veja os gráficos abaixo). Não obstante, e isso implica que se impõe um estudo mais aprofundado dos artigos em questão, é preciso notar que eles utilizam materiais biológicos, como por exemplo o DNA, que podem ser utilizados para objetivos totalmente diferentes dos estudos biológicos. Voltaremos a isso daqui a pouco.

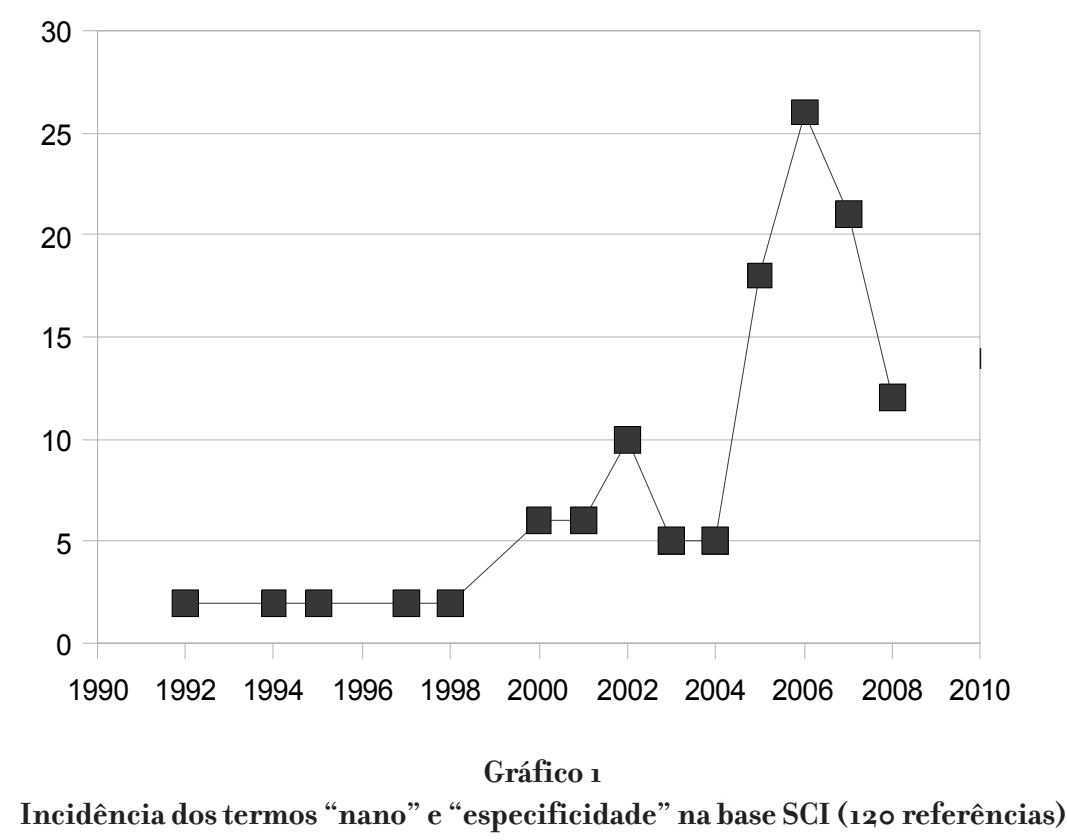

13 Sublinhamos ainda que em 2007 o GNRS lançou um edital, "Interface física-química-biologia: apoio ao correr riscos”, que insiste na importância de associar o desenvolvimento dessas três disciplinas. 


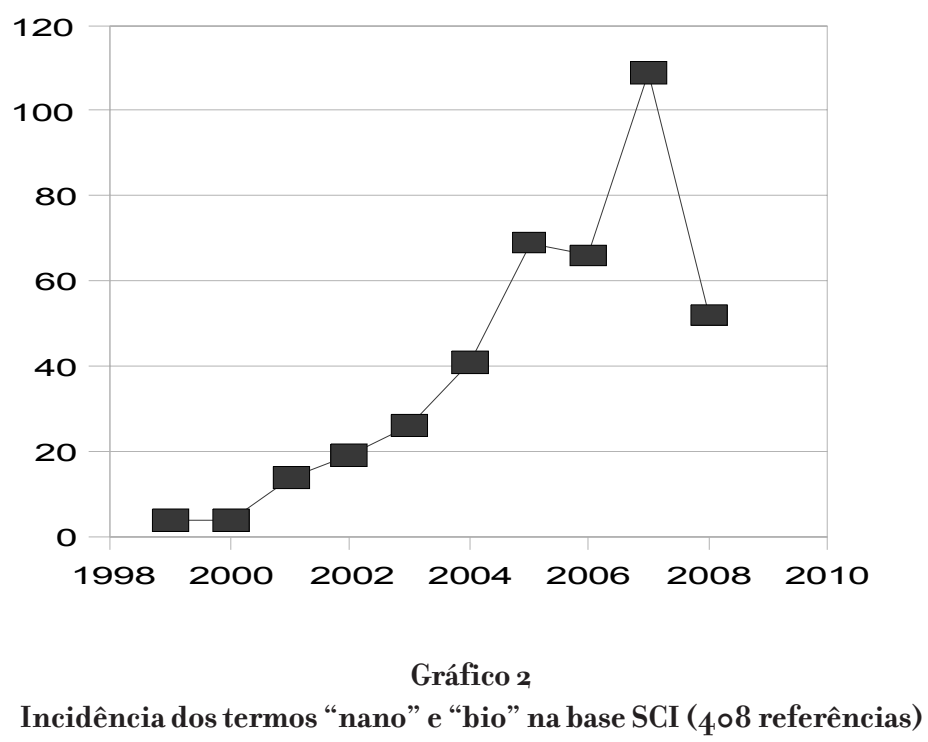

\section{NAtureza e ARtifício}

Todos esses elementos, que são comuns à biologia sistêmica e à biologia sintética, parecem dizer que os limites que as separam não são sempre fáceis de serem notados. Entretanto, como já havíamos dito, os objetivos perseguidos por cada um desses dois domínios, mesmo se a cultura técnica, instrumental e conceitual, na qual eles evoluem, é muito próxima, reconfiguram a linha divisória entre os dois.

Para os biólogos sintéticos, existe uma relação estreita entre o conhecimento de um sistema e a capacidade de reproduzi-lo artificialmente: não se conhece bem senão aquilo que se é capaz de fabricar. Para os biólogos dos sistemas, a caracterização e a descrição dos organismos vivos constituem um objetivo em si, por definição, inalcançável, na medida em que a vida não pode ser reduzida aos sistemas de explicação, por mais complexos que sejam.

Esse ponto tem uma conseqüência imediata sobre o estatuto da forma dos objetos estudados; enquanto para a biologia sistêmica essa forma inscreve-se na perspectiva da globalidade do ser vivente que a habita, para a biologia sintética, a lógica é totalmente diferente. No jogo de construção, elaborado a partir dos elementos do vivente que tentam isolar, controlar e manipular, o objetivo dos biólogos sintéticos vai além de uma compreensão do vivo. A lógica de pesquisa aplicada, na qual eles se inserem, descontextualiza e recontextualiza esses elementos em função dos objetivos e das propriedades que lhes querem atribuir, e que eles poderão repetir em contextos diferentes. 
Contudo, as moléculas do que é vivo têm tal nível de complexidade que fabricálas diretamente está ainda fora de alcance. Não são propriamente as moléculas que se vai procurar sintetizar ou transformar, mas o plano diretor que comanda seus contornos e suas funcionalidades. Como indica Morange (2003), a modificação de um organismo é concebida exatamente do mesmo modo como faríamos para um computador, cuja memória central fosse ampliada ou transformada graças ao acréscimo ou à substituição de certas unidades. Esses laboratórios conseguiram, por exemplo, introduzir as funções "on" e "off" nas bactérias e programar sua capacidade de emitir uma luz fluorescente em função de moléculas presentes em seu ambiente. Produziram-se moléculas de programação, "bio-tijolos" (disponíveis na internet) e transferiram-se, dessa maneira, de uma bactéria a outra, instruções biológicas. Esses programas induzem a síntese de moléculas específicas, a auto-montagem, no seio da célula, de módulos ou de redes moleculares determinadas.

Com essa idéia de auto-montagem de moléculas, tem-se a noção de que uma direção é dada à síntese química, a qual é, ela mesma, um processo "natural”. Faz-se o "design", o esquema geral daquilo que se quer que as moléculas façam ao se juntar. Os químicos e os biólogos, que se unem nessas pesquisas, são, indica Bensaude (no prelo), como os designers de móveis IKEA, que devem ser depois montados pelos compradores, ou como os maestros que dirigem um conjunto de músicos. O objetivo dos pesquisadores é a criação de funções que não existem na natureza; o que, por certo, lança as bases de uma bio-indústria de síntese, cujo impacto será, para eles, mais importante ainda que a indústria química de síntese da primeira metade do século xx.

Esses trabalhos suscitam problemas éticos evidentes. ${ }^{14}$ Além dos temores que as pesquisas de nanotecnologia fazem nascer, a torto e a direito, relativos ao ambiente e à saúde, em virtude de sua própria epistemologia, a biologia sintética suscita um problema suplementar ligado à descontextualização dos elementos do vivo, que ela consegue isolar, controlar e manipular: enquanto ela trabalha para reprogramar pedaços de DNA, ela concebe sua ação na escala limitada de seus objetivos próximos; mas ela leva em conta os riscos de uma transformação, a longo prazo, dos organismos vivos que ela manipula, ou daqueles que ela poderia contaminar com os primeiros? Mais amplamente, na imitação, no controle e nas transformações do que é vivo, onde estamos situados? No curto prazo dos objetivos a serem atingidos ou na perspectiva da constru-

14 Como indica claramente Rosnay, "esses trabalhos colocam importantes problemas na medida em que certos laboratórios sonham já com a fabricação de bactérias ou microalgas produtoras de hidrogênio (projeto de Craig Venter, cujo laboratório conseguiu recentemente sintetizar um vírus artificial), de biodetectores de poluição, ou ainda, de novas armas biológicas" (Rosnay, 2008). 
ção de um plano central organizado, capaz de produzir desordem, erros, mas também controle, auto-reparações e auto-regulação? Há um deslocamento da intervenção dos homens no processo geral da evolução?

\section{BRICOLAGEM OU ENGENHARIA}

Esses problemas, que a reflexão coloca no centro das relações entre a natureza e o artifício, dão à posição epistemológica dos pesquisadores na biologia dos sistemas ou na biologia da síntese, um lugar central para compreender seu modo próprio de considerar sua ação sobre a matéria.

Morange indica que o trabalho do pesquisador

parece mais um trabalho de bricolagem do que um trabalho de engenheiro ou arquiteto; estes últimos selecionariam os elementos confiáveis e, a partir deles, construiriam um edifício estável [...]. Os pesquisadores, ao contrário, dispõem apenas de tábuas podres, que apresentam uma probabilidade não nula de romper-se. Na maioria dos casos, o edifício desaba. Mas algumas vezes o edifício fica em pé. As tábuas podres que o constituem tornam-se cada vez mais seguras e consolidam-se ao mesmo tempo em que a construção progride (2003, p. 148).

Morange explica, além disso, que os biólogos sintéticos consideram-se a si mesmos como engenheiros com relação aos biólogos sistêmicos, que eles consideram como fazedores de bricolagem. Essa distinção poderia representar uma chave para apreender o liame cognitivo entre a natureza, que se explora, e o espírito no qual se trabalha. ${ }^{\mathbf{1 5}}$

$\mathrm{O}$ fato de considerar-se a si mesmo como "engenheiro" poderia ser associado à idéia de que, não somente, como se disse acima, não se conhece bem senão aquilo que se pode fabricar, mas ainda que não sendo a natureza perfeita, a ciência pode fornecer as armas para melhorá-la. Põe-se então a questão de saber qual é a visão que os "engenheiros" possuem dos processos de evolução, tal como eles se passam na natureza, e se essa visão é fundamentalmente diferente daquela que eles qualificam de "fazedores de bricolagem”. Ou, mudando os termos, o modo de considerar sua própria ação sobre a natureza estaria subentendido pelo modo de compreender a natureza e os grandes

15 Os termos "engenheiro" e "fazedor de bricolagem" representam, no momento, o que de melhor se dispõe para a caracterização da realidade bastante complexa que procuramos apreender. Eles permitem sintetizar terminologicamente a visão que os pesquisadores têm de sua própria atividade e de sua perspectiva sobre a evolução das relações entre a epistemologia, que organiza sua visão de mundo, e os modos de ação sobre a natureza, que eles têm em vista para conduzir seus trabalhos. 
mecanismos da dinâmica da vida? Retomando a problemática proposta acima, em que medida a perspectiva que a ciência tem de sua própria ação sobre a natureza, seja como fazedora de bricolagem seja como engenheiro, está inscrita em uma concepção determinada da vida e de sua evolução? Em uma tal perspectiva e levando a reflexão até o limite, os "fazedores de bricolagem" poderiam, então, ser classificados ao lado daqueles que, como Goethe a propósito de Laoconte, ou ainda Bohr, em sua visão reducionista da vida, haviam conduzido a biologia à renúncia de explicar "a vida"? E, com muita nuance e precaução, poder-se-ia classificar os "engenheiros" em uma perspectiva mais mecânica e modular, associando unidades de vida descontextualizadas e reconfiguradas para preencher objetivos particulares, onde a imbricação de formas assim reunidas desempenha uma parte comparável àquela da correlação de formas de Cuvier?

Mais certamente, ainda que muito esquematicamente, pode-se perguntar se existe uma separação entre os defensores de uma concepção da evolução, certamente tateante, mas extremamente complexa e ramificada, sobre a qual não se pode ter um impacto determinado, e aqueles que privilegiariam a idéia de uma evolução sobre a qual é possível, ao contrário, uma ação técnica dirigida e controlada. Responder a essa questão poderia servir de evidência para uma epistemologia diferenciada e para a existência de comunidades científicas particulares, a dos biólogos sintéticos e a dos biólogos sistêmicos.

A pós-modernidade (cf. Forman, 2007; Shinn, 2008) apagou as fronteiras principalmente entre a ciência e a tecnologia (cf. Hottois, 2006) e fortaleceu a tendência a diminuir as fronteiras entre as disciplinas, contribuindo, em certa medida, para reconfigurá-las, retraçando os contornos pela criação de sinergias e de circulação inéditas entre elas. Tentar ligar uma operação científica a sua epistemologia apropriada permitiria talvez ver aonde se formam as novas fronteiras que delimitarão as comunidades de pesquisadores e que perenizarão as relações entre a natureza, tal como delimitada pelas questões e pelos instrumentos produzidos para estudá-la, e a cultura que construiu essas questões e esses instrumentos. A linhagem de sujeitos que decorre disso segue, em si mesma, uma lógica que constrói progressivamente territórios, a história de um pensamento e o desenrolar progressivo do fio dos pressupostos epistemológicos que subentende todas essas operações.

\section{As Formas dos OBJEtos "NANo"}

Essas diferentes questões colocam em cena a escala nanométrica. Mas esta não parece representar, para os biólogos, a ruptura, nem o termo unificador que lhes permite definirem-se ou definir uma linha de pesquisa. Como na física, intervêm, na evolução da biologia, novos instrumentos como o AFM e outros mais específicos (eletroforese de 
fase gasosa); mas como vimos, mais ainda talvez os instrumentos cognitivos (a simulação, por exemplo), sustentados por computadores cada vez mais poderosos, que trabalham em rede. Os desafios das transformações da ciência da vida parecem situar-se alhures, e bem mais provavelmente na convergência e no enfraquecimento das fronteiras entre os domínios, nos quais se originaram a biologia sistêmica e a biologia sintética. Em troca, a colaboração de disciplinas diferentes entre si em torno de projetos elaborados conjuntamente, complexos, obriga, a longo prazo, cada pesquisador a reconfigurar os limites do território no interior do qual trabalha.

$\mathrm{O}$ que parece distinguir, enquanto pertencentes a comunidades distintas, os biólogos sistêmicos e os biólogos sintéticos é evidentemente sua posição com relação aos fins da aplicação. Mas mais fundamentalmente, tentou-se mostrar que, ao fim e ao cabo, é talvez sua respectiva posição com relação à fronteira entre o vivo e o não vivo, sua visão da evolução e sua ação sobre a natureza, sua percepção das formas e das configurações da vida; donde se segue que a inserção de um organismo no conjunto mais vasto ou, ao contrário, sua descontextualização, poderia tornar-se como que o emblema daquilo que os separa.

Essa descontextualização é levada a seu termo nos trabalhos conduzidos por químicos e físicos a partir de materiais biológicos como o DNA e, nesse contexto, a forma dos objetos utilizados adquire um lugar ainda mais central. As pesquisas de Paul Rothemund e Paul Winfree do California Institute of Technology, ${ }^{\mathbf{1 6}}$ mostram de modo surpreendente a importância da configuração das moléculas que se escolhe com relação aos fenômenos que nelas se estudam: eles procuraram utilizar "telhas de DNA" como suporte para a elaboração de cálculos (não se fala ainda em criar um computador quântico): eles relatam que não conseguiram localizar na "telha" as informações que eles recolheram e que tinham validade para o projeto. Utilizando a "função AFM-intermitente" (microscópio de força atômica com modo intermitente), ${ }^{17}$ eles colocaram em evidência que esses dados não provêm de sua espessura, nem de seu tamanho, mas das bordas irregulares da telha, ou seja, de sua forma acidentada. Pode-se assim colocar a questão de saber qual é a epistemologia de base que subjaz aos trabalhos que utilizam esses materiais biológicos, como se faria para qualquer outro material a fim de estudar fenômenos físicos: não é a vida e o mistério de sua reprodução que interessa, mas as propriedades particulares de certas substâncias que contribuem para organizá-la.

16 Pesquisas que lhes valeram o prêmio Feynman em 2006 por sua "Teoria para um computador molecular e um algoritmo de auto-montagem" ("Theory in molecular computation and algorithmic self-assembly").

17 O microscópio de força atômica (AFM) é um tipo de microscópio com sonda local que serve para visualizar a topografia da superfície de uma amostra. O princípio está baseado nas interações entre a amostra e uma ponta montada sobre uma micro alavanca. A ponta percorre a superfície a representar, agindo sobre a altura segundo um parâmetro de retroação. Um computador registra as alturas e pode assim reconstituir uma imagem da superfície. 
Ao apagar as fronteiras entre o artificial e o natural, o surgimento das nanociências e nanotecnologias dá aos objetos da pesquisa uma espécie de amovibilidade entre dois estatutos: o biológico torna-se utensílio em programas de pesquisa da física, enquanto esses programas tornam-se parceiros indispensáveis das ciências da vida, para reprogramar uma célula, por exemplo, ou construir nanomáquinas, ou ainda, em pesquisas com objetivo claramente de diagnóstico ou terapêutico.

Assim, por exemplo, os oligopeptídeos com os quais trabalham os biólogos que constroem imagens moleculares, ${ }^{\mathbf{1 8}}$ são obtidos por "seleção darwiniana". ${ }^{19}$ A natureza sobre a qual se trabalha é, desse modo, fragmentada, dissociada do processo geral de sua evolução, dirigida para funcionalidades pré-definidas. Elaboram-se, dessa maneira, materiais biológicos, tais como, por exemplo, os aptômeros, ${ }^{20}$ que se podem associar com objetos tais como as caixas quânticas, ${ }^{\mathbf{2 1}}$ maiores, as quais são facilmente produzidas; continua-se a partir daí a explorar um organismo e a efetuar um diagnóstico.

As diferentes questões que abordamos aqui sublinham a importância da relação - configurada pela tecnologia no estado de conhecimento em um domínio dado da ciência, em suma, em um contexto científico e cultural dado - entre os objetos da natureza, tal como se pode observá-la e manipulá-la, e esse contexto cultural. Serge Moscovici observou que a idéia de natureza está amplamente construída nos artifícios que a natureza pode produzir, para utilizá-la ou explorá-la (cf. Moscovici, 1977; Guchet, no prelo). As epistemologias contrastantes, que tentamos distinguir, poderiam constituir-se em objeto de análises que integrariam essa perspectiva, em particular, com as noções de destinação, de finalidade, no sentido da direção que toma o esforço de conhecimento, da intenção fundamental que se encontra no centro dos projetos de exploração do mundo e da natureza.

18 A construção de imagens moleculares é uma nova disciplina que visualiza o funcionamento das células e os processos moleculares do que é vivo.

19 A "seleção darwiniana" é uma seleção interativa de geração em geração. Inverte-se o processo normal da evolução. No processo normal, um casal de pais terá uma descendência que vai evoluir pouco a pouco aumentando sua ocupação do ambiente e, em função da seleção do ambiente, do clima, da nutrição, o mais apto sobrevive. A “seleção darwiniana" artificial faz o inverso. Ela parte de uma população bastante grande (14 elevado a 10 indivíduos), e exerce sobre ela restrições cada vez mais fortes, até obter uma população bastante menor, mas tendo as características determinadas.

20 Categoria particular de RNA, capaz de fixar ligantes. Um ligante é uma molécula que se fixa a uma proteína. Essa fixação dispara em geral um efeito: modificação de uma atividade enzimática, no caso de um ligante alostérico, resposta celular, no caso de um receptor membranoso, de um receptor citoplásmico ou de um receptor nuclear de uma célula. 21 As caixas quânticas são constituídas de nanocristais inorgânicos. Muito mais brilhantes, emitindo por durações bastante mais longas que os fluoróforos orgânicos - elas são virtualmente isentas de foto branqueamento -, essas novas sondas expandem os limites da imagem por fluorescência em termos de detecção de antígenos pouco representados e de captura de imagens em tempo real. 


\section{Formas do vivo, Linhagens de PESQuisa e inVARIANTeS}

Tal como aparece nas pesquisas sobre a vida, a noção de forma põe em perspectiva dinâmicas que poderiam parecer, à primeira vista, estranhas entre si. Contudo, ela cristaliza as epistemologias apropriadas ao encadeamento de temas de pesquisas no seio das disciplinas científicas concernidas, inscrevendo em vínculo necessário, a operação dos pesquisadores nas questões fundamentais sobre a origem da vida, sobre a fronteira entre a natureza e o artifício, entre o vivo e o não vivo. Nas entrelinhas, que se erigem por vezes para delimitar as lógicas no modo de apreender a natureza, enfraquecidas em certos momentos, reforçadas, estabilizadas ou mais móveis em outros, poder-se-ia, desse modo, fazer emergir a definição de comunidades de pesquisadores.

Essa perspectiva supõe a existência da invariabilidade dos conceitos e das idéias que, de modo mais ou menos explícito, são como que princípios organizadores da atividade científica. A idéia de invariância implica que os mesmos elementos reencontram-se em graus diferentes e que contribuem para estruturar a realidade, dando-lhe, por meio dos arranjos ou das combinações entre si, uma força diferente, desaparecendo para ressurgir mais adiante sob a forma de simples traço ou de armadura essencial. Assim, poucas coisas parecem separar os biólogos sistêmicos dos biólogos sintéticos. Contudo, cada um deles define-se em função de uma concepção da vida que se poderia ligar às seguintes invariâncias: para os primeiros, as formas dos objetos se inscrevem em uma perspectiva de globalidade,enquanto, para os segundos, elas são indicadas enquanto módulos descontextualizáveis. Eles se ligam, assim, a epistemologias diferentes e a comunidades científicas que, por serem muito próximas, até por vezes comuns, não procuram por suas delimitações apropriadas.

A noção de invariância, contra a qual Michel Foucault se indispôs (cf. Veyne, 2008), que parte da idéia de que o estoque de conceitos para explicar o mundo é, no final das contas, limitado, parece a priori colocar, em um plano secundário, o contexto no qual eles adquirem uma espessura e desenvolvem-se em uma época dada. Na realidade (cf. Marcovich, 2001), eles não têm um valor heurístico e não apresentam interesse senão na medida em que são encarnados nas lógicas, restrições, nuances, desenvolvimentos, obstáculos e problemáticas do contexto científico particular que neles investe. Essa contextualização pode ter como efeito torná-los difíceis de identificar, mas ela contribui também, pela diversidade das formas sob as quais ela se faz descobrir, para apreender-lhes a riqueza e para compreender suas filiações.

Em seu artigo, Bensaude põe a questão de saber se entre a química mimética de Leduc, que "imita as estruturas biológicas com os procedimentos químicos", e a biologia sintética, que "imita as sínteses químicas com os materiais biológicos", forma-se um jogo de espelhos ou antes se essas operações afastadas por um século reencontram-se 
nas invariâncias. A idéia de espelho implica a de comparação, de pôr sob o olhar, de contraste, de simetria, mas também de confrontação, de deslocação entre duas realidades. Ela permite, talvez ao mesmo tempo, fazer surgir, como faz Bensaude, a noção de limiar (como aquela entre o vivo e o não vivo, ou mesmo entre o vivo e o morto no contexto da medicina clínica, entre o artificial e o natural), e procurar como se pode recompor, para além desses limiares, a epistemologia de disciplinas científicas.

Essas noções de invariância e espelho fazem correr o perigo de que se estabeleçam correlações artificiais entre épocas, contextos, operações e disciplinas diferentes. É necessário afastar-se desse risco, propondo, como simples hipóteses, os moldes comuns aos conceitos distanciados nos tempos e nos espaços disciplinares. No entanto, essas noções permanecem esclarecedoras, principalmente para estudar a sociologia e a epistemologia de ciências, que trabalham na escala nanométrica e que, talvez mais do que as outras, estão presas a lógicas institucionais e científicas que apagam as fronteiras e os territórios próprios a cada uma. A questão da invariância poderia, assim, conduzir a essa questão particular que pertence ao fundamento da epistemologia, na qual se inscreve toda operação científica, e que permite avaliar a relação entre essa operação, a comunidade particular que a toma a cargo e os objetos da natureza que ela estuda.@ 


\begin{abstract}
Questions related to forms and morphology acquired a central position in the sciences after the XvIII $^{\text {th }}$ century, particularly in biology. Since 1890, forms entered into biochemistry starting from the notion of specificity (fit among molecules is said to be like that of key and lock). Different orientations in biology (particularly after the molecular biology revolution and the development of systemic biology, synthetic biology and works clearly oriented to the nanometric scales) have attributed different meanings to the notions of form and specificity. The different perspectives - on the one hand, those in which these notions are used, mainly in connection with the question of boundaries between the living and the nonliving, and between nature and artificial and, on the other hand, those in which they are eliminated, replaced, for example, by the notions of information and code - could provide the key to understanding the deep epistemology of research in these areas, and the "paradigms" that bring together researchers who begin their work in distinct scientific communities. The analysis proposed here is mainly based on the idea of invariability of concepts and ideas that, more or less explicitly, can resemble organizing principles of scientific activities.
\end{abstract}

KEYwords $\bullet$ Molecular biology. Systemic biology. Synthetic biology. Scientific community. (Des)-contextualization. Epistemology. Form. Boundary. Invariability. Model. Specificity.

\title{
REFERÊNGIAS BIBLIOGRÁFICAS
}

AвіR-Aм, P. G. The first american and french commemorations in molecular biology: from collective memory to comparative history. Osiris, 14, p. 324-72, 1999.

BAsu, S. et al. A synthetic multicellular system for programmed formation. Nature, 4,34, p. 113o-4, 2005 .

Bensaude, V. B. Biomimetic chemistry and synthetic biology: A two-way traffic across the borders. Actes de la Conférence "Pour une évaluation critique des bionanotechnologies. Perspectives éthiques et philosophiques". 25-26 janvier 2008, Paris, École Normale Supérieure. Paris: Vuibert. No prelo.

Guvier, G. Recherches sur les ossements fossiles de quadrupèdes, où l'on rétablit les caractères de plusieurs espèces d'animaux que les révolutions du globe paroissent avoir détruits. Paris: [s./n.], 1812. 4v.

Danghin, A. Préface. In: Schrödinger, E. Qu'est-ce que la vie? De la physique à la biologie. Paris: Point Seuil, 1992. p. 7-28.

Flourens, P. Buffon. Histoire de ses travaux et ses idées. Paris: Paulin Libraire Editeur, 1844.

Forman , P. The primacy of science in modernity, of technology in post modernity, and of ideology in the history of technology. History of Technology, 1-2, p. 1-152, 2007 .

Guchet, X. Les conceptions de la nature dans les nanotechnologies. Le cas des machines moléculaires artificielles. Actes de la Conférence "Pour une évaluation critique des bionanotechnologies. Perspectives éthiques et philosophiques". 25-26 janvier 2008, Paris, École Normale Supérieure. Paris: Vuibert. No prelo.

Ноттогs, G. Méthodologie. La technoscience: de l'origine du mot à ses usages actuels. Recherche en Soins Infirmiers, 86, p. 25-32, 2006.

Iвraнim, A La notion de moule intérieur dans les thèories de la gènèration au xviıIe siècle. Archives de Philosophie, $5^{\circ}$, p. $555^{-80}, 1987$.

Leduc, S. Mechanism of life. Disponível em: <http://www.archive.org/details/mechanismoflifeo29804 $\mathrm{MBP}>$. Acesso em: 20/05/2008.

Marcovich, A. A quoi rêvent les sociétés? Paris: Odile Jacob, 2001.

Morange, M. Histoire de la biologie moléculaire. Paris: La Découverte, 2003.

Moscovici, S. Essai sur l'histoire humaine de la nature. Paris: Flammarion, 1977. 
Formas Do VIVO E No VIVO: IMITAR E/OU REPRODUZIR A VIDA

Ретітот, J. Morphologie et esthétique. Paris: Maisonneuve/Larose, 2004.

Rosnay, J. de. Biologie de synthèse: enjeux et défis pour l'humanité. Transversales, Sciences \& Culture, 13/12/2004. Disponível em: <http://grit-transversales.org/article.php3?id_article=44 > Acesso em: 20/06/2008.

SAUvaGe, J. P. Les nanomachines moléculaires: de la biologie aux systèmes artificiels et aux dispositifs. Disponível em: 〈http://culturesciences.chimie.ens.fr/NanomachinesJPSauvage.pdf $>$. Acesso em: 20/06/2008.

Schrödinger, E. Qu'est-ce que la vie? De la physique à la biologie. Paris: Point Seuil, 1992 [1944].

Shinn, T. Desencantamento da modernidade e da pós-modernidade: diferenciação, fragmentação e a matriz de entrelaçamento. Scientiae Studia, 6, 1, p. 41-79, 2008.

VeYne, P. Foucault, sa pensée, sa personne. Paris: Albin Michel, 2008. 